\title{
Remodeling of B-50 (GAP-43)- and NSE-immunoreactive Mucosal Nerves in the Intestines of Rats Infected with Nippostrongylus brasiliensis
}

\author{
Ron H. Stead, ${ }^{1,2,5}$ Urszula Kosecka-Janiszewska, ${ }^{1,2}$ A. Beate Oestreicher, ${ }^{6}$ Michael F. Dixon, ${ }^{5}$ and John \\ Bienenstock ${ }^{2,3,4}$ \\ IIntestinal Disease Research Unit, Departments of ${ }^{2}$ Pathology and ${ }^{3}$ Medicine, and 4 Molecular Virology and Immunology \\ Program, McMaster University, Hamilton, Ontario, Canada L8N 3Z5, ${ }^{5}$ Department of Pathology, University of Leeds, \\ Leeds, England LS2 9JT, and 'Division of Molecular Neurobiology, Rudolf Magnus Institute, University of Utrecht, \\ The Netherlands
}

Intestinal mucosal mast cells (IMMCs) are closely apposed to nerves, which is consistent with other evidence suggesting that mast cells are innervated. Recent studies have indicated that coordinated changes in mast cell and nerve densities occur in the gut mucosa, during progressive fibrosis, but there is a lack of experimental evidence to support remodeling of intestinal nerve fibers as part of a disease process. Infection of rats with the nematode Nippostrongylus brasiliensis $(\mathrm{Nb})$ results in an initial loss of stainable IMMCs, during an acute inflammatory phase, with subsequent mast cell hyperplasia. Accordingly, we employed the Nb model to look for structural neuroplasticity of intestinal mucosal nerves during inflammation.

Immunocytochemical labeling of neurofilament subunits was very low in the jejunal mucosa of all animals, whereas neuron-specific enolase (NSE)-immunoreactive nerves were relatively abundant in control animals. The number of NSEimmunoreactive profiles increased approximately 2.5 -fold by day $10(d 10)$ postinfection $(p<0.01)$ and returned to near control values by d14. Immunoreactivity for B-50/GAP43 was more extensive, labeling more than four times the number of nerves per villus, compared with NSE $(p<0.0001)$. B-50 immunoreactivity decreased minimally (ca. $20 \%$ ) by $\mathrm{d} 7$ postinfection, and then increased through control values between $d 10$ and $d 21$, to $30 \%$ greater than controls at $d 49$ ( $p$ $<0.05)$. Subclassification of the B-50-immunoreactive nerves according to cross-sectional area revealed a greater than twofold increase in the proportions of large fibers at $\mathrm{d7}$ and d10. Subsequently, the proportions of small nerves were increased compared with controls. The fiber size changes were found to correlate with mast cell densities $(r=-\mathbf{0 . 7 2}$ for large and $r=0.76$ for small nerves). At d10, dilated

\footnotetext{
Received Feb. 1, 1991; revised July 1, 1991; accepted July 17, 1991.

We thank Drs. K. Croitoru, E. E. Daniel, and J. Diamond for their comments on the manuscript, and we gratefully acknowledge E. C. C. Colley, K. HowesJones, S. Lohtak, R. Macaluso, S. Toms, and L. Ure-Hardsand for their expert assistance. Dr. C. H. Goldsmith kindly provided advice on statistics, and Dr. P. D. M. Macdonald generously helped with distribution analysis. This work was supported by the Medical Research Council of Canada.

Correspondence should be addressed to Ron H. Stead, Department of Pathology, Room 3N10, McMaster University Health Sciences Centre, 1200 Main Street West, Hamilion, Ontario, Canada L8N $3 Z 5$.

Copyright (c) 1991 Society for Neuroscience $0270-6474 / 91 / 113809-13 \$ 05.00 / 0$
}

B-50- and NSE-immunoreactive nerves predominated, and extraneuronal NSE was noted. Electron microscopy revealed that this was due to axonal dilation and degeneration.

These data provide evidence for plasticity of intestinal mucosal nerve fibers during inflammation. This includes early degenerative and later regenerative phases that appear to correlate with mast cell densities. The phenotype of mucosal nerves in control animals suggests ongoing modeling of these fibers.

Activation of connective tissue mast cells (CTMCs) causes the release of numerous mediators, resulting in vascular changes and the recruitment and activation of other immune cell types (Galli and Austen, 1989; Stevens and Austen, 1989; Galli, 1990). CTMCs are often associated with nerve bundles, and several reports suggest that mast cells can be activated by neurocrine mechanisms (see Stead et al., 1987a, 1990b), although there are contradictory findings regarding the effects of nerve stimulation on mast cell activation (Kowalski and Kaliner, 1988; Dimitriadou et al., 1990; Kiernan, 1990; Kowalski et al., 1990). Nevertheless, the concept of neurogenic inflammation can be partly explained by the action of released neuropeptides on CTMCs (Foreman and Jordan, 1984).

Evidence is also accruing for interactions between nerves and intestinal mucosal mast cells (IMMCs), which are phenotypically and pharmacologically different from classical CTMCs (see Stead et al., 1990b). We and others have documented an intimate and extensive association of IMMCs with mucosal nerves in several species (Newson et al., 1983; Seelig et al., 1985; Yonei et al., 1985; Stead et al., 1987b, 1989, 1990a; Yonei, 1987; Arizono et al., 1990). There is also evidence that the release of an IMMC-specific protease, rat mast cell protease II (RMCP II), can be psychologically conditioned using an audiovisual cue paired with antigenic challenge (MacQueen et al., 1989).

In a recent study on surgically resected human appendices, we determined a significant correlation between mast cell and nerve densities in the lamina propria of relatively normal specimens (Stead et al., 1990a). Furthermore, in samples exhibiting minimal fibrosis, both mucosal mast cell and nerve densities were increased, and in specimens with extensive fibrosis these were both reduced. The proposition that there might be coordinated changes in the densities of mast cells and nerves has broad implications and suggests that more mast cells should be 


\begin{tabular}{ll}
\hline Table 1. Time course of experiments with $\mathbf{N b}$-infected rats \\
\\
$\begin{array}{ll}\text { Time of death } \\
\text { (d after Nb infection) }\end{array}$ \\
\hline Experiment 1 & 0 (controls) \\
$(n=3)$ & 7 \\
& 14 \\
& 18 \\
& 21 \\
& 28 \\
& 35 \\
Experiment 2 & 10 \\
$(n=5)$ & 24 \\
& 37 (controls) \\
& 49
\end{tabular}

Lewis rats (male, 150-200 gm) were infected with $\mathrm{Nb}$ at $\mathrm{d} 0$ and killed at the above times. $n$ represents the number of animals killed at each time point for that experiment.

${ }^{a}$ Noninfected control animals were killed at $\mathrm{d} 37$.

found near growing nerve fibers, which is certainly true in amputation neuromas (Olsson, 1968; Nennesmo and Reinholt, 1986). Moreover, axonal sprouting or neuronal hypertrophy should be seen in diseased tissues where mast cell hyperplasia has been recorded, namely, inflammation. Evidence for this is purely circumstantial, such as the neuronal hypertrophy in Crohn's disease, where the reported degree of mast cell hyperplasia and ncuropcptide lcvels are variable (Ranlov ct al., 1972; Rao, 1973; Lloyd et al., 1975; Pepys and Edwards, 1979; Bishop et al., 1980; Dollberg et al., 1980; Dvorak et al., 1980a,b; Sjolund et al., 1983; Koch et al., 1987, 1988). Even the close patterns of change of mast cell and nerve densities seen in the fibrosing appendix are only suggestive of this (Stead et al., 1990a).

In laboratory-reared rats the density of IMMCs is relatively low ( $<5$ cells per villus/crypt unit) but is known to change significantly after infection with Nippostrongylus brasiliensis $(\mathrm{Nb})$ (Befus and Bienenstock, 1979; Befus et al., 1979). Infection with this nematode causes an initial decrease in the number of stainable mast cells, presumably due to degranulation, during an acute inflammatory phase with accompanying edema, epithelial changes, and some villus atrophy (Symons and Fairbairn, 1962). Subsequently, after worm expulsion (at about 2 weeks postinfection), the acute inflammation subsides and a mast cell hyperplasia, which persists for scveral wecks, is observed. Many investigations have been done on this hyperplastic population, including our own work on the innervation of mucosal mast cells. However, we have not previously taken into account the fact that the mucosal innervation might also change during $\mathrm{Nb}$ infection. The current study was designed primarily to look for structural remodeling of nerves in $\mathrm{Nb}$-infected rats and, secondarily, to determine if any such changes are temporally related to mast cell densities.

We employed immunocytochemistry for the characteristic neuronal markers neuron-specific enolase (NSE) and neurofilaments (NF), as well as for B-50 (GAP-43), a nerve growthassociated molecule found in relative abundance in regenerating nerves and areas of high synaptic plasticity (Benowitz and Routtenberg, 1987; Skene, 1989). Mast cells were stained with Alcian blue at low pH in parallel sections. Electron microscopy was also utilized to evaluate the effect of inflammation on the mucosal nerves. Our data show extensive remodeling of B-50- and
NSE-immunoreactive mucosal nerves after $\mathrm{Nb}$ infection. This consists of degeneration during the acute inflammatory phase and regeneration thereafter, which are coordinated with the phases of mast cell degranulation and subsequent hyperplasia. Moreover, in noninfected rats, we found extensive B-50 immunoreactivity of mucosal nerves and relative paucity of NF in this compartment, which invites the suggestion that the mucosal innervation might be continually modeling.

An abstract of these data was presented previously (Stead et al., 1990c).

\section{Materials and Methods}

\section{Animals}

Male Lewis rats (Charles River Laboratories, Quebec, Canada) were housed in filter-topped cages and given food and water ad libitum. Two series of animals were infected subcutaneously with 2000-3000 stage L3 larvae of Nippostrongylus brasiliensis (Stead et al., 1987b). Noninfected rats were killed at the start (experiment 1) or near the end (experiment 2) of the time course of the experiments (Table 1). All animals were killed with ether anesthesia and cervical dislocation before being promptly autopsied.

\section{Tissue fuxation and processing}

Light microscopy. Pieces of jejunum were opened and immersed in either acetic acid/ethanol (1:9; AA), or $10 \%$ neutral buffered formalin (NBF) (Stead et al., 1987b). After 6-8 hr fixation, the NBF-fixed samples were transferred to $70 \%$ ethanol for $2 \mathrm{hr}$, and then all samples were processed to paraffin. Some blocks were embedded on edge, and others with the mucosal face down, to facilitate the production of longitudinal and cross sections of jejunal villi, respectively. Sections were cut at 2 $\mu \mathrm{m}$, collected on aminopropyltriethoxysilane-coated slides (Burns et al., 1987), dried overnight at $45-50^{\circ} \mathrm{C}$, and used for immunocytochemistry within 1 week. Routine hematoxylin and eosin (H\&E)-stained en face and transverse sections were prepared. From some animals, pieces of tongue were fixed and processed in parallel as positive controls for immunohistochemistry.

Electron microscopy. Small pieces of jejunum were opened and immersed in $2 \%$ glutaraldehyde in $0.1 \mathrm{M}$ sodium cacodylate buffer at $4^{\circ} \mathrm{C}$. Tissues were fixed for $2 \mathrm{hr}$ before $1 \mathrm{~mm}^{3}$ blocks were postfixed in osmium tetroxide, processed, and embedded in Spurr's resin with the mucosal face down to provide cross sections of the villi. Semithin sections were stained with $1 \%$ toluidine blue in $1 \%$ borax and examined to select areas for electron microscopy. Ultrathin sections $(60 \mathrm{~nm})$ were stained with uranyl acetate and lead citrate and examined in a Jeol 1200 EX transmission electron microscope.

\section{Histochemistry}

Scctions from the AA-fixed blocks cmbedded en face were staincd with $1 \%$ Alcian blue in $0.5 \mathrm{~m} \mathrm{HCl}(\mathrm{AB} 0.5)$ for $2 \mathrm{hr}$. These were pre- and postrinsed in $0.5 \mathrm{M} \mathrm{HCl}$ to prevent background staining.

\section{Immunocytochemistry}

AA-fixed sections were used for the localization of neuron-specific enolase and B-50 (GAP-43). Polyclonal rabbit anti-NSE (Dako, Cat. \#A589, from Dimension Laboratories, Mississauga, Ontario, Canada) was diluted 1:100 in Tris-buffered saline, pH 7.6 (TBS), containing 5\% normal swine serum (TBS/NSS), and then absorbed with $100 \mathrm{mg} / \mathrm{ml}$ of normal rat muscle and liver powders and demonstrated using the peroxidase anti-peroxidase (PAP) method (Stead et al., 1987b). Aftinity-purified rabbit anti-B-50 immunoglobulins, raised against purified rat B-50 (antiserum 8420) (Oestreicher and Gispen, 1986; Gorgels et al., 1989) were diluted 1:5000 in TBS/NSS, applied overnight, and labeled using the Zymed streptavidin/biotin/peroxidase Histostain SP Kit (Dimension Laboratories) (Stead et al., 1989). Both NBF- and AA-fixed tissues were used to localize neurofilament subunits. Monoclonal antibodies NR4 (68 kDa), NN18 (160 kDa), NE14 (phosphorylated, $200 \mathrm{kDa})$, and N52 (phosphorylated and dephosphorylated, $200 \mathrm{kDa}$ ) (Shaw et al., 1986), from Boehringer Mannheim, Montreal, Quebec, as well as 2F11 (70 and $200 \mathrm{kDa}$ ) from Dako, were diluted 1:5 (or greater in some experiments) in TBS/NSS containing $0.1 \%$ Triton-X. These were applied overnight and detected using the Zymed streptavidin/biotin/peroxidase Histostain 
SP system. Negative control sections included substitution of the primary antiserum with an immunoglobulin fraction of normal rabbit serum for the polyclonal anti-NSE and anti-B-50, and the use of diluent alone for the anti-NFs. Additionally, absorption of the anti-B-50 with homologous B-50 antigen $(10 \mu \mathrm{g} / \mathrm{ml})$ was performed. For all sections, peroxidase activity was demonstrated using aminoethylcarbazole. Staining was not observed in any of the negative control sections.

\section{Quantitation}

All light -microscope determinations were made using a Videoplan image analysis system (Zeiss, Toronto, Ontario, Canada) with kONTRon software, version 5.41. Measurements were made either by examining the stained microscope slides directly, at the same time as viewing the illuminated cursor and digitizing tablet through a drawing tube, or from photographic transparencies. Magnification factors were determined by making multiple measurements of a micrometer slide or photomicrographs of this.

For the electron micrographs, an IBAS image analysis system (Reichert-Jung UK, Slough, England) was employed. The IBAS was operationally identical to the Videoplan, with the same software. Scaling for this was done by tracing the scale bars from 20 prints and deriving a mean.

Alcian blue stains. Mast cell density was determined at $100 \times$ magnification using the drawing tube. A minimum of 10 cross sections of jejunal villi per animal were assessed by tracing the margins of the lamina propria with the automatic closure window set at $0.2 \mathrm{~mm}$ and counting the number of AB0.5-stained cell profiles in that area. The total mast cell count and integrated lamina propria area were used to determine a mast cell density for cach animal.

$B-50(G A P-43)$ immunoreactivity. In order to standardize the staining of sections from different animal groups, sections from all rats in the first experiment were stained in a batch, as were sections from all animals in experiment 2. Three cross sections of villi were assessed in each slide, resulting in a total of nine villi per experimental time point. In some sections, some villi appeared dilated with a flattened epithelium and others looked normal; both types were included in the assessment.

The number, density, and area of nerve fibers were measured in the B-50 (GAP-43)-stained slides at $1000 \times$ magnification, using a drawing tube. The circumference of each nerve profile was traced with the automatic closure window set at $0.2 \mathrm{~mm}$. The area of lamina propria was then determined at $100 \times$ magnification. A total of 4792 nerve fibers from 83 villi in three animals from each experimental group were measured.

NSE immunoreactivity. Slides from all animals in experiments 1 and 2 were stained together to minimize variability. The intensity and sharpness of staining of many of the nerve profiles in the NSE-immunostained slides was substantially less than for B-50. Consequently, the use of a drawing tube for measurement of nerve sizes was not practicable. Accordingly, color photomicrographs were prepared on transparency film using both $25 \times$ and $40 \times$ objectives. These were subsequently backprojected onto the Videoplan digitizing tablet, resulting in final magnifications of approximately $625 x$ and $1000 \times$. Three photomicrographs were prepared from each animal at the lower magnification, enabling entire villi to be contained in most instances, and five pictures were taken at the higher magnification. A few of these photomicrographs were rejected from the subsequent analysis because of lack of contrast. The $25 \times$ photographic transparencies were used to determine villous lamina propria areas and nerve numbers; nerve profile areas were measured in the $40 \times$ slides.

Electron micrographs. After rejecting poorly oriented tissue blocks from toluidine blue-stained semithin sections, ultrathin sections were examined in the electron microscope and again screened for orientation. Only villi appearing in good cross section, without pseudostratification of the epithelium, were used for assessment of nerve areas. These villi were scanned through the binocular eyepieces at a nominal $3000 \times$ magnification (final magnification, 30,000 $\times$ ), and all recognizable nerve profiles, except for those falling on grid bars, were photographed at $5000 \times$. This resulted in a total of 141 nerves being sampled in 28 villi from 18 blocks in 12 animals.

Prints were prepared at a final magnification of $12,500 \times$. Each photograph was then analyzed using the IBAS. The micrographs were placed on the digitizing tablet, the circumferences of the nerves were traced, and the axons were counted. The morphometric parameters derived from this measurement procedure included area, ellipse factor, minimum diameter, maximum diameter, axon number, and axon density.

\section{Analysis of data}

Nerve size classes. To assess the change in distribution of nerves after $\mathrm{Nb}$ infection, the nerve profile areas from B-50-stained slides were classified into three groups. These were derived by pooling the nerve areas of both control groups [day 0 (d0) in experiment 1 and d37 in experiment 2] and determining their mean and standard deviation (SD). "Average" nerves were classified as those with areas within one SD of the mean; small and large nerves, as those lying outside of these boundaries. To determine if any new or separate populations of B-50-immunoreactive nerves emerged, MIX software (version 3.0; Ichthus Data Systems, Hamilton, Ontario, Canada) was employed. This program was written specifically for the analysis of mixtures of distributions (Macdonald and Pitcher, 1979).

Trimming nerve areas. Estimates of the mean axon areas for each nerve were derived by division of the measured nerve arca by axon number, without allowance for any nonaxonal component. For regression analysis, however, the measured nerve areas and axon counts were used, and these were "trimmed" to remove outlying values that may have given an overassessment of the relationship between axon number and nerve area. This was done by excluding fibers with an ellipse factor of 0.33 or less (length : width ratio of more than $3: 1$ ). Also, for regression only, to allow for slightly oblique sections, "probable" nerve areas were computed as the area of a circle based on the minimum fiber diameter (Weibel, 1979).

Statistical analysis. The raw data were analyzed using MINITAB version 6.1 statistical software. Analysis of variance (ANOVA) was employed to determine overall differences in the various nerve parameters over the time course of $\mathrm{Nb}$ infection. Rootogram analysis of the residuals from ANOVA was uscd to assess statistical normality of thc data (Clcveland, 1988). In all analyses performed, the values in a total of only three bins extended minimally beyond the boundaries. This was not considered significant enough to warrant the use of nonparametric statistics. For specific comparison of d0 and d37 control animal groups, Student's $t$ test (two-sided, $\alpha=5 \%$ ) was employed. However, for multiple pairwise comparisons of data from infected and noninfected rats, we determined Tukey's wholly significant difference allowance (Dunnett and Goldsmith, 1989) using Studentized range tables for $\alpha=1 \%$ and $\alpha=$ $5 \%$ (Miller, 1981). Linear regression $(b)$, correlation coefficients $(r)$, and coefficients of determination $\left(r^{2}\right)$ were also calculated.

\section{Results}

\section{Morphological assessment of inflammation in experimental animals}

Histological changes. H\&E-stained slides of control animals were unremarkable, but sections from $\mathrm{Nb}$-infected animals showed characteristic pathological changes (Taliaferro and Sarles, 1939). An acute cellular infiltrate was observed in the jejunal mucosa of animals $7 \mathrm{~d}$ postinfection, with marked epithelial degeneration and crypt hyperplasia. At d10, variable degrees of villous atrophy were noted, with the epithelium frequently showing signs of regenerative hyperplasia. The lamina propria appeared even more distended after 2 weeks, containing a mixture of inflammatory cells including a few polymorphs, but the epithelium appcarcd within normal limits. The density of the cellular infiltrates gradually declined thereafter, being almost but not quite normal at d49. Nematodes were seen in the first three infected groups but were not noted after $\mathrm{d} 14$.

Distribution of mast cells. AA-fixed sections stained with AB0.5 revealed several mast cells in the lamina propria in control animals, but these were only occasionally seen 7 and $10 \mathrm{~d}$ after infection. Mast cells were visible in the sections from animals killed $14 \mathrm{~d}$ or more after $\mathrm{Nb}$ infection, occupying a large part of the lamina propria at $\mathrm{d} 18$ and $\mathrm{d} 21$. Thereafter, the density of IMMCs declined but was persistently greater than control animals.

\section{Effect of inflammation on the gastrointestinal mucosal nerves}

Normal mucosal innervation. In routine transverse sections of the gut wall, NSE was found to label many nerve fibers through- 

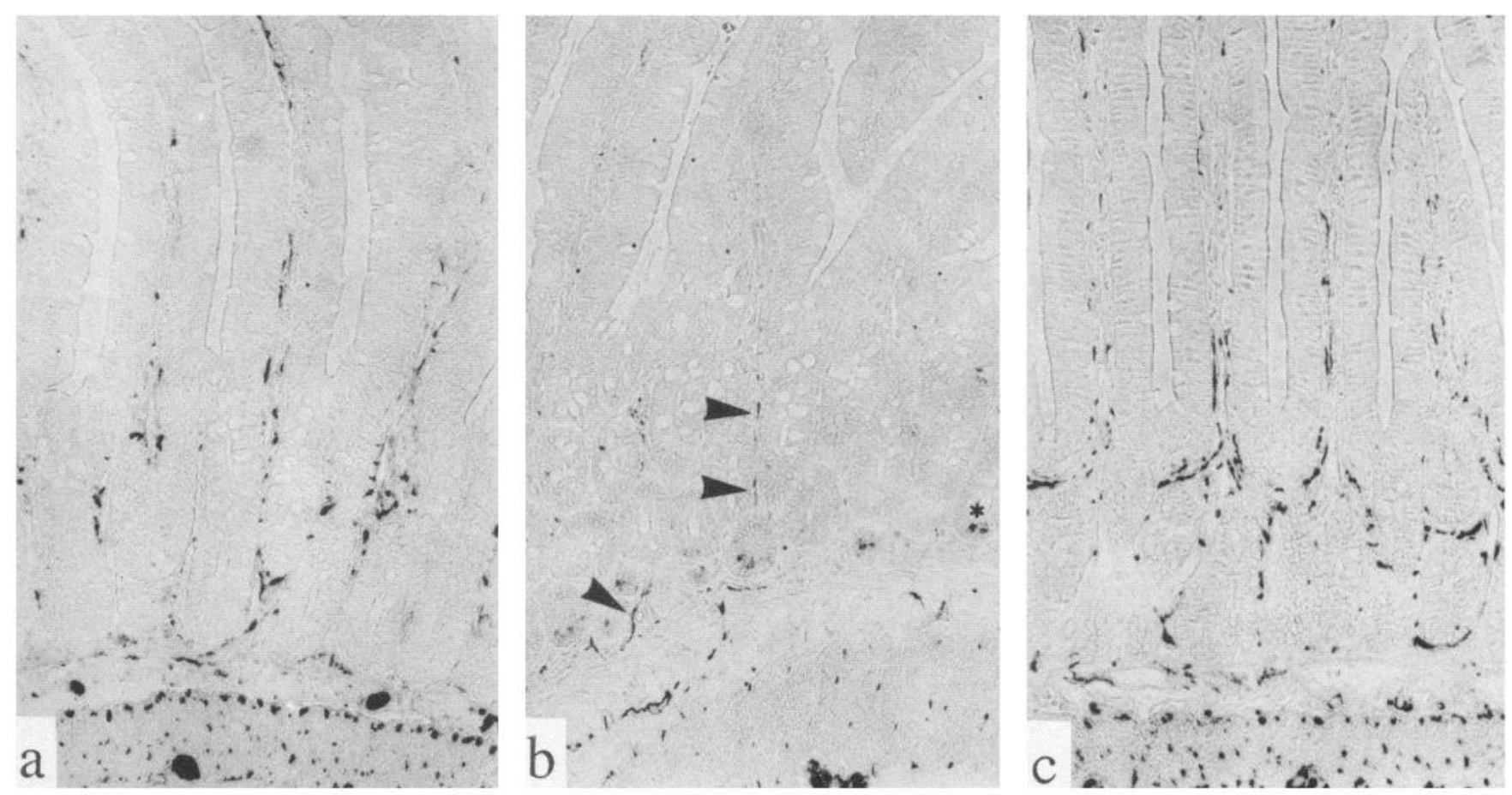

Figure 1. Relative distribution of NSE, NF (200 kDa), and B-50 in the jejunal mucosa: routine transverse sections of rat jejunum illustrating immunoreactivity for NSE $(a), 200 \mathrm{kDa}$ NFs $(b)$, and B-50 (c). Many B-50- and NSE-labeled nerve fibers are stained throughout the gut wall in $a$ and $c$; however, the distribution of NFs is much less, with only occasional fibers extending into the mucosa $(b$, arrowheads). Paneth cells in the crypts (one of which is marked with an asterisk) were also weakly immunolabeled with this monoclonal antibody (NE14). Magnification, 130 $\times$.

out the mucosa, extending up to the tips of the villi, as well as nerve plexi in the submucosa and muscularis propria (Fig. 1a), as reported previously (Stead et al., 1987b). In comparison, NF immunoreactivity was sparse in the nerve networks in all layers of the gut wall, with only a few labeled mucosal fibers in the pericryptal lamina propria but none in the villi (Fig. $1 b$ ). This was seen with the anti-200 kDa NF clone NE14. The other monoclonal anti-NF antibodies (NR4, NN18, N52, 2F11) gave less extensive staining, but all intensely stained nerves in the control sections of tongue. In contrast, B-50 (GAP-43) immunoreactivity (Fig. 1c) appeared even more extensive than the NSE staining, with abundant sharply outlined fibers extending up to the tips of the intestinal villi, but nerve bundles in the tongue sections were not labeled.

Mucosal nerves in inflamed intestines. In sections showing villi in longitudinal section (as in Fig. 1), there was little apparent change in the pattern of innervation after $\mathrm{Nb}$ infection, except for some thickened B-50- and NSE-immunoreactive nerves in some villi in animals killed at $\mathrm{d} 10$. To observe better any changes in the mucosal nerve fibers, we examined sections of jejunum embedded en face, to produce cross sections of the leaf-shaped villi. In these preparations, the densities of B-50-NSE-immunoreactive mucosal nerves were clearly different but the patterns of changes for both of these antigens over the time course of inflammation were similar (Fig. 2). In some villi from 1-2 week postinfection animals, thickened nerves containing B-50 and NSE were prominent, and extraneuronal NSE staining was apparent. Subsequently, at about d18-21, fine nerve fibers predominated, and these stained very weakly for NSE. The pattern of innervation in sections from animals 5 and 7 weeks after infection looked like controls, although increased nerve density was apparent in the d49 B-50 slides.

Ultrastructural observations. Nerves were readily identifiable in all grids examined. In control animals these sometimes appeared to be normal, consisting of variable numbers of axons with neurosecretory vesicles, microtubules, or fine filaments (Fig. $3 a$ ), although such typical axonal components were often lacking. In comparison to control animals, striking ultrastructural differences were seen at dl0, including disruption of the connective tissue matrix of the villous lamina propria and the presence of large, sometimes tortuous nerve profiles and phagocytelike cells adjacent to nerves (Fig. $3 b-d$ ). There was also evidence of nerve degeneration, with some fibers containing myelin figures (Fig. 3d) and other dilated axon-like profiles containing a particulate matrix, similar to degenerating axons described elsewhere (Asbury and Johnson, 1978). Animals 24 and $49 \mathrm{~d}$ after infection also contained some larger nerve profiles and active phagocytes, although the lamina propria was not disrupted in these animals.

\section{Quantitation of mucosal nerve remodeling}

Comparison of $d 0$ and $d 37$ noninfected animals. Comparison of the $\mathrm{d} 0$ and $\mathrm{d} 37$ controls did not reveal statistically significant differences: B-50 nerve number, $t(16)=-0.53, p=0.61$; NSE nerve number, $t(20)=-0.58, p=0.57$; B-50 nerve density, $t(16)=-1.25, p=0.23$; NSE nerve density, $t(28)=0.21, p=$ 0.84 . The overall means \pm SE for controls were as follows: B-50 nerve number, $46.3 \pm 3.0(n=18)$ fibers per villus; NSE nerve number, $11.1 \pm 1.6(n=22)$ fibers per villus; B-50 nerve 

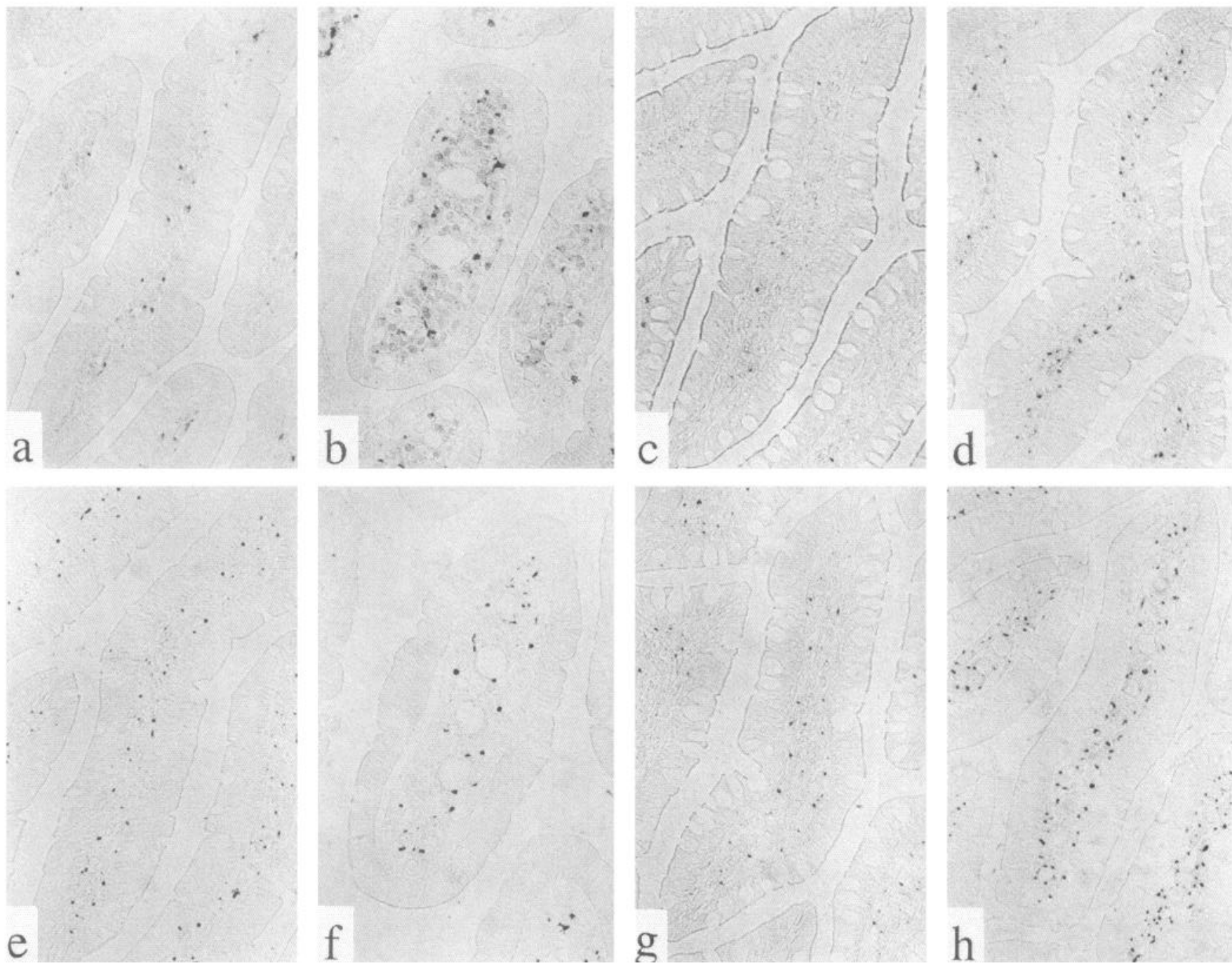

Figure 2. Change of pattern of B-50- and NSE-immunoreactive nerves after $\mathrm{Nb}$ infection: cross sections of intestinal villi from blocks embedded with the mucosal face down and carefully trimmed to ensure that sections through the mid-villus region were obtained. Samples were taken from rats killed at $\mathrm{d} 0$ (control; $a$ and $e$ ), $\mathrm{d} 10(b$ and $f), \mathrm{d} 18(c$ and $g)$, and $\mathrm{d} 49(d$ and $h)$ after Nb infection. Both NSE $(a-d)$ and B-50 $(e-h)$ immunoreactivities are illustrated. Larger nerve profiles are seen in the dilated villi in the d10 animals than in controls, in both NSE and B-50 preparations. Diffuse (presumably extraneuronal) NSE immunoreactivity is also seen at d10. In sections from animals killed $18 \mathrm{~d}$ postinfection $(c$ and $g$ ), mainly finer nerve fibers are observed. At d49 ( $d$ and $h)$, sharp staining of numerous nerve fibers immunoreactive for NSE or B-50 are observed in normalappearing villi. Magnification, $160 \times$.

density, $5.1 \pm 0.3$ fibers $\mathrm{mm}^{-2}(n=18)$; NSE nerve density, 1.0 \pm 0.1 fibers $\mathrm{mm}^{-2}(n=30)$.

Nerve number and density. These data are presented as the number of labeled nerves per villus (Fig. $4 a$ ), as a measure of the absolute loss or gain of demonstrable nerve fibers, and as nerve density (Fig. $4 b$ ), which takes into account the changing volume of the villi due to edema and cellular infiltration (the mean lamina propria cross-sectional area more than doubled from d0 to d10: $9.3 \pm 1.9 \times 10^{3} \mu \mathrm{m}^{2}$ vs. $23.0 \pm 6.6 \times 10^{3} \mu \mathrm{m}^{2}$ in B-50-stained slides). The number of nerves labeled for B-50 was consistently greater than for NSE. In d0 controls, B-50 staining revealed more than four times the number of nerves per villus than did NSE $(44.67 \pm 10.31$ vs. $9.71 \pm 4.68 ; t(14)$ $=8.28 ; p<0.0001$ ).

In the NSE slides, the number of measurable nerves increased 2.5 -fold by d 10 postinfection $(p<0.01)$ and declined to approximately control numbers thereafter. The density of NSE- immunoreactive fibers decreased after infection, with the most significant reduction occurring at about 3 weeks $(p<0.05$ at d24). In the B-50-stained slides there was an initial slight decline in the number of nerves per villus and a significant drop in density, being lowest at $\mathrm{d} 14(p<0.01)$. Compared with controls, nerves were increased in number in all groups over 3 weeks postinfection and increased in density 5 and 7 weeks after $\mathrm{Nb}$. At d49, both of these were statistically significant $(p<0.05)$.

Mean nerve areas per villus. Determination of nerve areas in both NSE and B-50 preparations confirmed a significant, greater than twofold increase in mean nerve cross-sectional area at d 10 (mean $\mu \mathrm{m}^{2}$ per villus \pm SE: B-50: $4.74 \pm 0.37$ at $\mathrm{d} 0$ vs. 11.11 \pm 0.91 at $\mathrm{d} 10, p<0.01$; NSE: $1.71 \pm 0.20$ at d0 vs. $5.13 \pm$ 0.30 at d10, $p<0.01$ ). This then subsided, being lower than controls between $\mathrm{d} 18(3.36 \pm 0.11)$ and d $35(4.06 \pm 0.24)$ in the B-50 preparations, and between $\mathrm{d} 24(1.47 \pm 0.22)$ and $\mathrm{d} 49$ $(1.68 \pm 0.22)$ in the NSE slides, although these changes were 

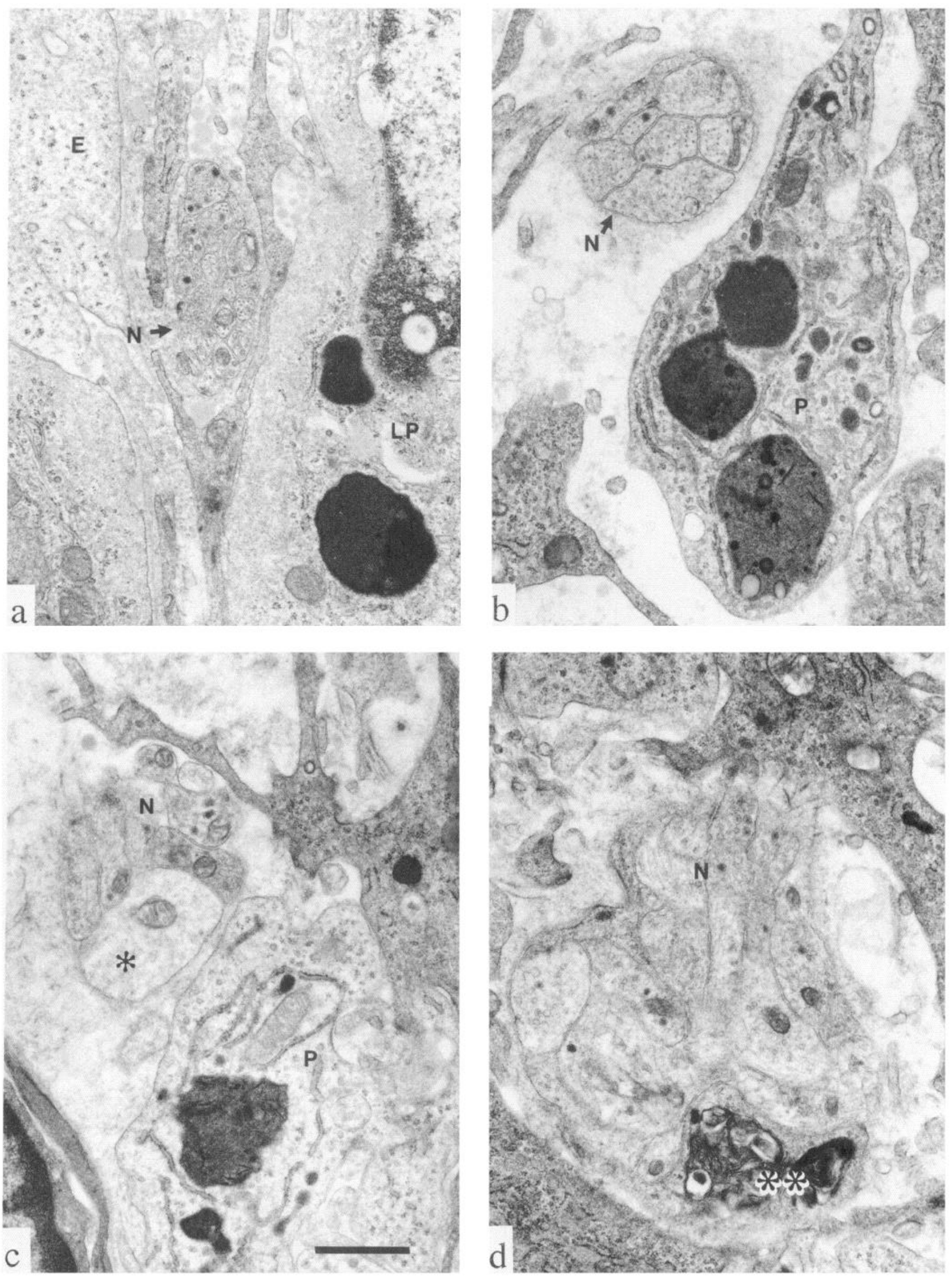

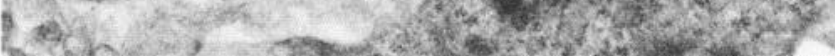

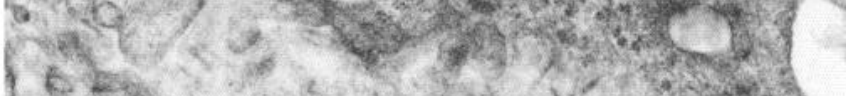

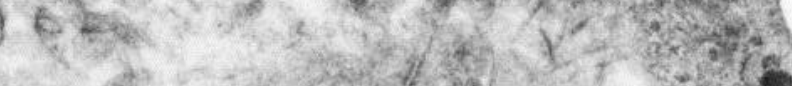

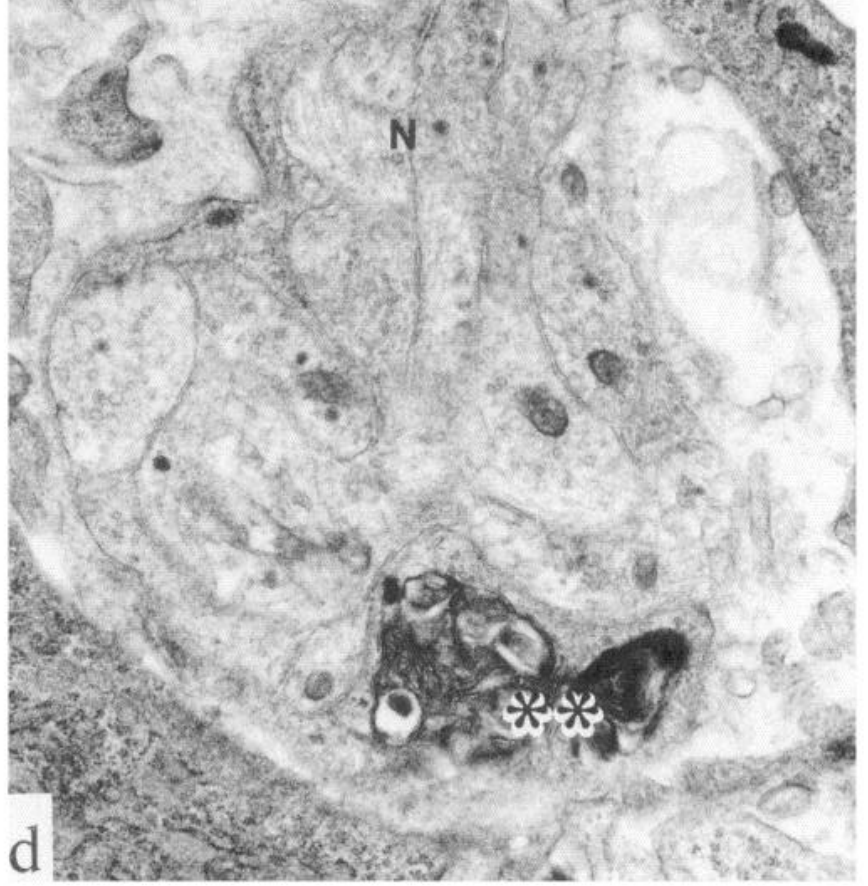



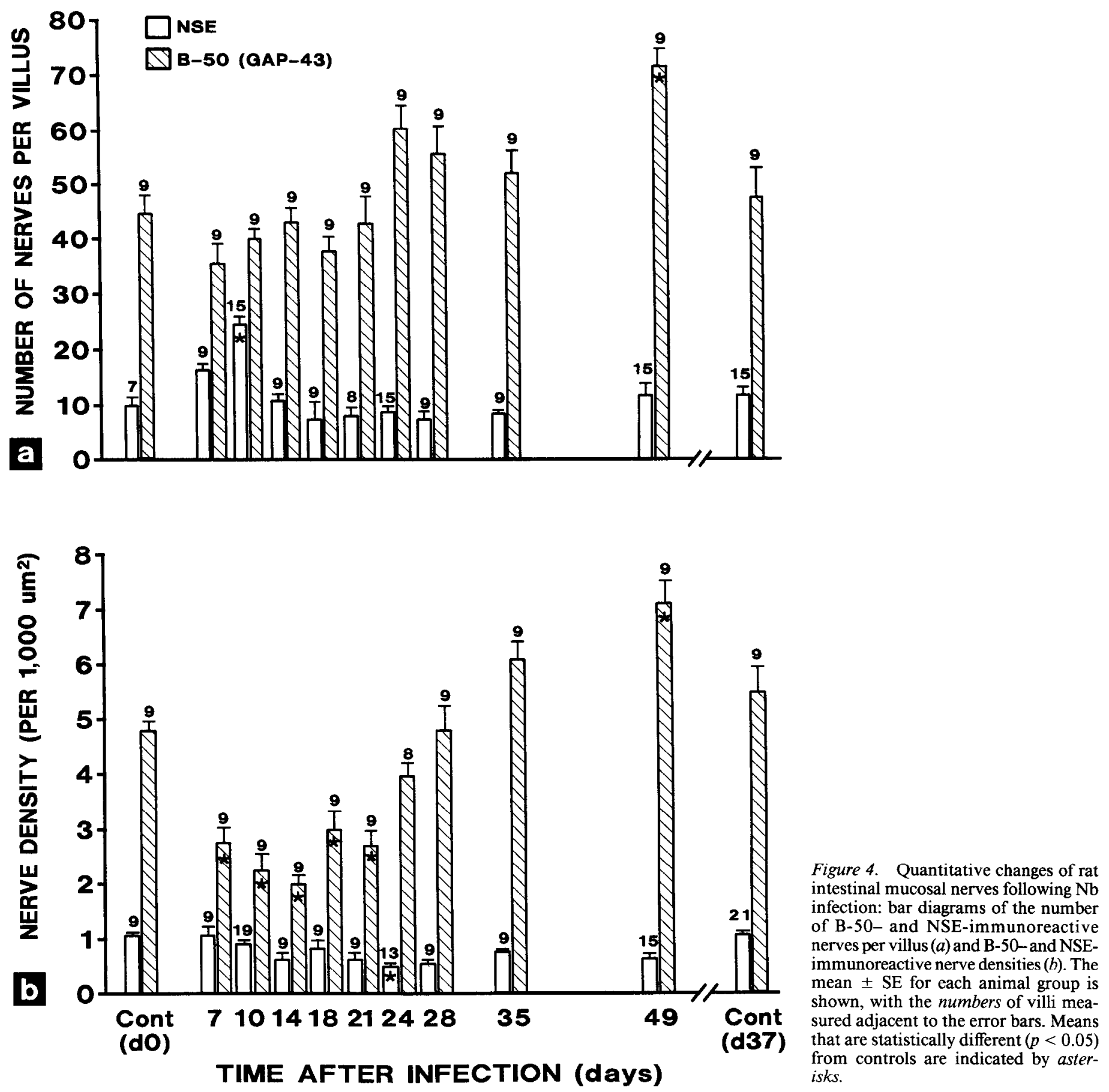

not statistically significant. The $\mathrm{d} 37$ control mean nerve areas were $5.08 \pm 0.21 \mu \mathrm{m}^{2}$ for B-50 and $2.35 \pm 0.15 \mu \mathrm{m}^{2}$ for NSE.

Measurement of electron micrographs. Since many nerves in postinfection animals appeared ultrastructurally within normal limits, we measured the cross-sectional areas of such fibers in electron micrographs and determined the number of axons in each nerve (Table 2). The mean measured nerve area was found to increase more than twofold $10 \mathrm{~d}$ after infection and was still greater than controls at $\mathrm{d} 24$ and $\mathrm{d} 49$. This was statistically significant for $\mathrm{d} 10(p<0.01)$ animals only. The number of axons

Figure 3. Comparison of nerves in normal intestinal mucosa with dilated and degenerating profiles observed at d10 postinfection: electron micrographs showing cross sections of nerve fibers from a control rat $(a)$ and animals killed at d $10(b-d)$, representing several stages of degeneration. Relatively small axonal profiles are secn tightly bundled in a subepithelial nerve $(N)$ in a compared with much larger axons in the nerve surrounded by disrupted lamina propria in $b$. In some nerves, both degenerating $(*)$ and relative normal axons were seen $(c)$. Many larger, tortuous fibers were also seen at $\mathrm{d} 10(d)$, containing dilated axons and myelin figures $\left.{ }^{* *}\right)$. Phagocytic cells $(P)$ are also illustrated in $b$ and $c$. These were often seen associated with nerves and prominent in postinfection animals, sometimes engulfing free axons. $E$, epithelium; $L P$, lamina propria. Magnification, $17,500 \times$; scale bar, $1 \mu \mathrm{m}$. 


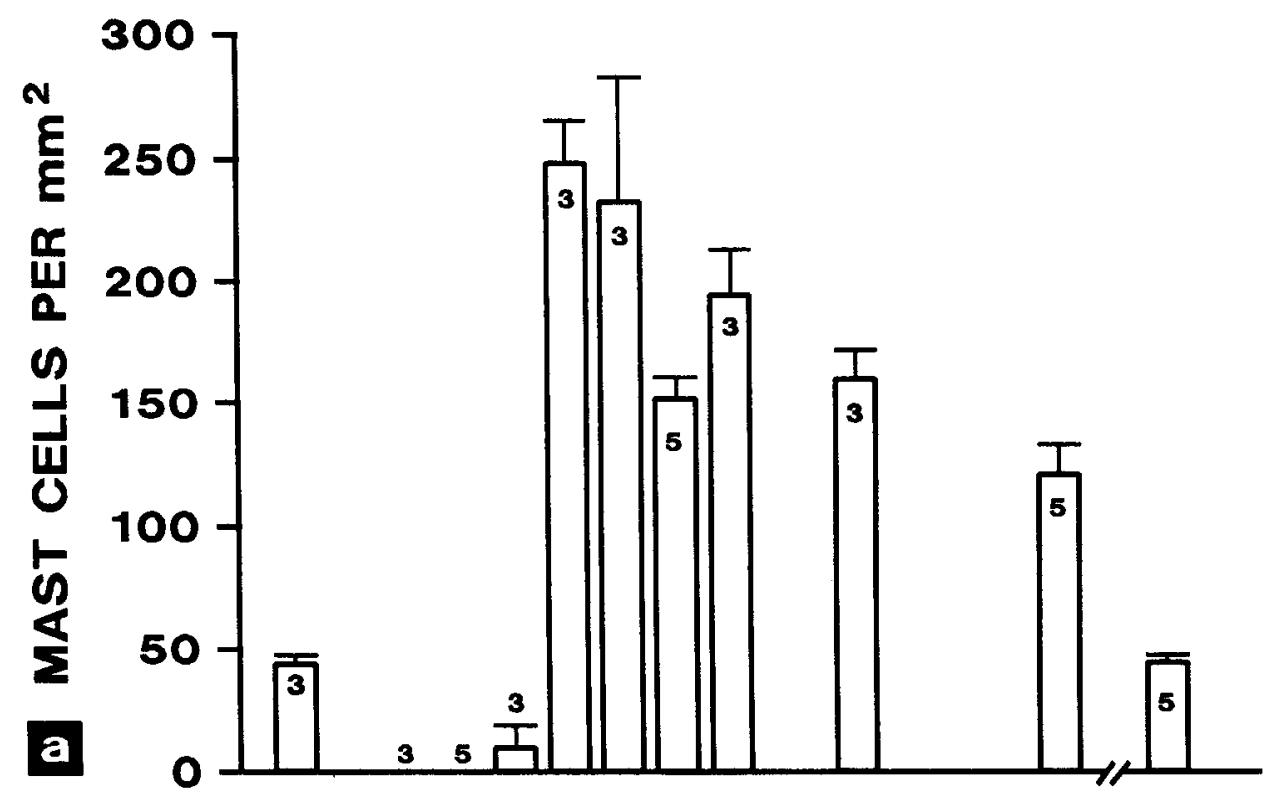

Figure 5. Quantitative changes of mast cell density and nerve fiber size in rat intestinal mucosa following $\mathrm{Nb}$ infection: bar diagrams of Alcian bluestained mast cell densities $(a)$ and B-50immunoreactive nerve fiber sizes $(b)$. In $a$, the mean \pm SE mast cell density for each animal group is shown, with the numbers of animals adjacent to the erfibers classified in three different crosssectional area categories are shown (see Materials and Methods). ror hars. In $b$, the proportions of nerve

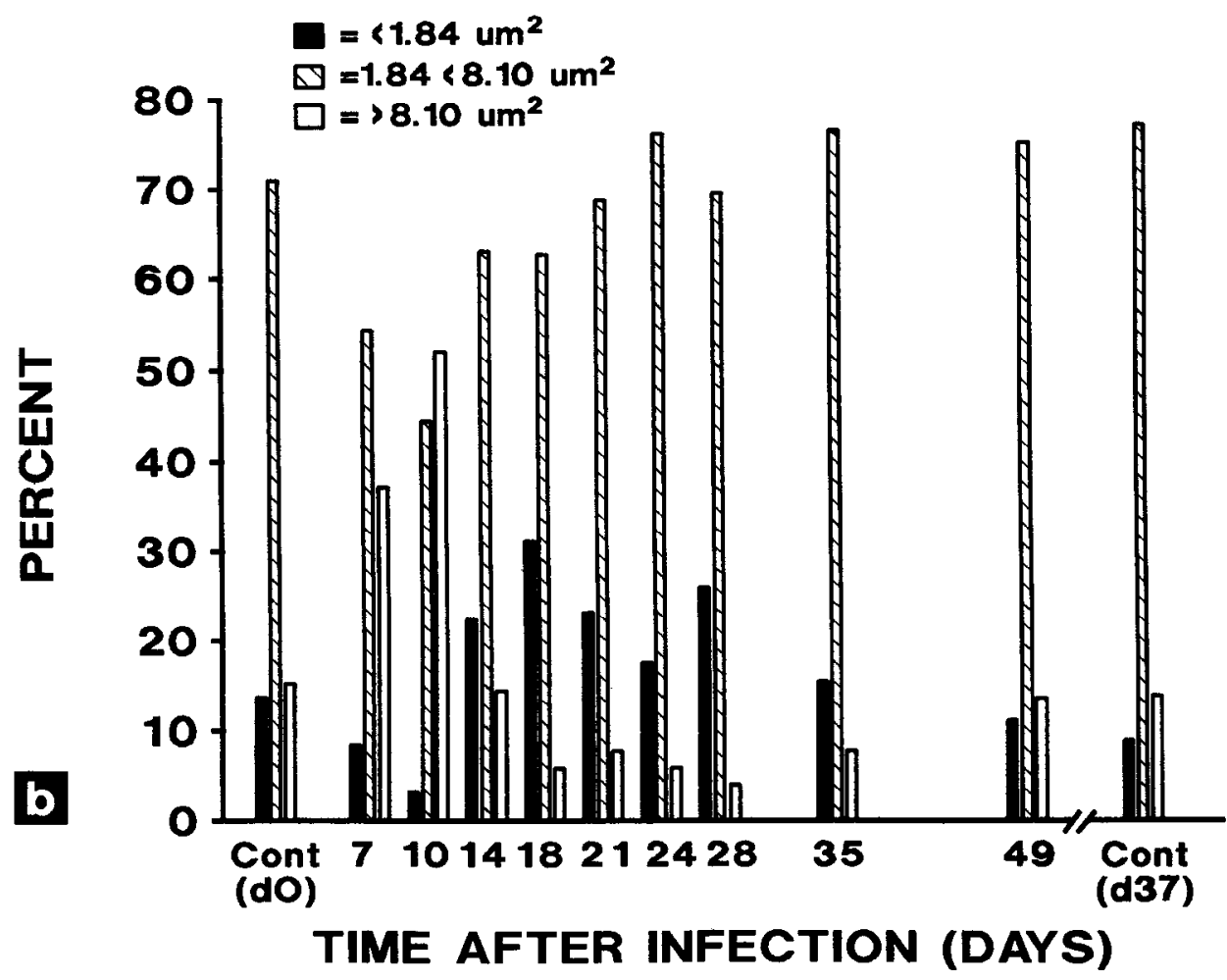

present in each nerve did not vary significantly $[F(3,137)=2.51$; $p=0.062$; see Table 2]; however, calculated axonal areas increased more than twofold $\left(0.15 \pm 0.06 \mu \mathrm{m}^{2}\right.$ in controls vs. 0.35 $\pm 0.15 \mu \mathrm{m}^{2}$ in $\mathrm{d} 10$ post- $\mathrm{Nb}$ animals), and regression analysis revealed that although nerve size was dependent upon axon number $(r=0.58-0.65)$, the regression coefficient was three times larger at d 10 postinfection than in controls.

Changes in mast cell density. Quantitation of the $\mathrm{AB} 0.5$ stains confirmed the loss of mast cells at $d 7-10$ and revealed approximately five times more mast cells $18 \mathrm{~d}$ after infection than in control animals $(p<0.01$; Fig. $5 a)$. This was followed by a gradual decline in mast cell number, although at the last time examined (d49), the mast cell density was still almost three times that seen in the noninfected animals.

Fiber size distribution after $\mathrm{Nb}$ infection. When the B-50immunoreactive nerve profiles were classified into three size groups (Fig. $5 b$ ), the pattern of "large" nerves resembled the changes recorded for mean villus nerve area and nerve number per villus in the NSE slides. In contrast, there was an initial drop in the number of small nerve fibers followed by increased 
Table 2. Electron microscopy data

\begin{tabular}{|c|c|c|c|c|c|c|c|c|c|c|c|c|c|}
\hline \multirow[b]{2}{*}{$\underline{\text { Day }}$} & \multicolumn{3}{|c|}{ Nerve area } & \multicolumn{3}{|c|}{ Axon number } & \multicolumn{2}{|c|}{ Axon area } & \multicolumn{5}{|c|}{ Regression analysis } \\
\hline & $n$ & Mean & $\mathrm{SD}$ & $n$ & Mean & $\mathrm{SD}$ & Mean & SD & $n$ & $r$ & $b$ & $r^{2}$ & $p<$ \\
\hline Control (d37) & 34 & 3.07 & 1.48 & 34 & 21.71 & 9.87 & 0.15 & 0.06 & 30 & 0.62 & 0.06 & 0.39 & 0.001 \\
\hline Infected $\mathrm{d} 10$ & 40 & 6.31 & 5.45 & 40 & 17.40 & 9.78 & 0.35 & 0.15 & 35 & 0.62 & 0.18 & 0.38 & 0.001 \\
\hline Infected d 24 & 34 & 4.82 & 2.30 & 34 & 16.65 & 7.14 & 0.32 & 0.14 & 28 & 0.58 & 0.11 & 0.34 & 0.001 \\
\hline Infected d49 & 33 & 4.56 & 5.42 & 33 & 20.67 & 9.47 & 0.22 & 0.17 & 28 & 0.65 & 0.11 & 0.42 & 0.001 \\
\hline ANOVA & \multicolumn{3}{|c|}{$\begin{array}{l}F(3,137)=3.79 \\
p=0.012\end{array}$} & \multicolumn{3}{|c|}{$\begin{array}{l}F(3,137)=2.51 \\
p=0.062\end{array}$} & \multicolumn{7}{|c|}{$\begin{array}{l}F(3,137)=16.79 \\
p<0.001\end{array}$} \\
\hline
\end{tabular}

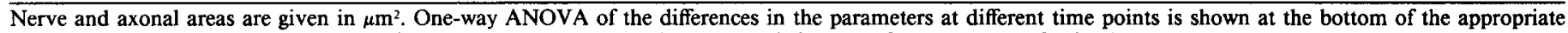
columns. Rcsults of rcgression analysis of axon number per measured nerve area is included for each group of animals.

proportions after d14. Using the MIX program, up to three lognormal populations of nerves (classified into $0.4 \mu \mathrm{m}^{2}$ bins) would fit the data, although a single lognormal population gave an acceptable fit for several time points (data not shown). Importantly, new populations could not be found in postinfection animals; however, populations of "small" nerves (mean area using $\mathrm{mix} \approx 2 \mu \mathrm{m}^{2}$ ) could be defined in both control and infected mucosae. These nerves were found to increase in proportion after 2 weeks postinfection (e.g., mean area $\pm \mathrm{SE}$, proportion $\pm \mathrm{SE}$ for $\mathrm{d} 0: 1.73 \pm 0.56 \mu \mathrm{m}^{2}, 0.20 \pm 0.16 ; \mathrm{d} 18: 1.80 \pm 0.41$ $\mu \mathrm{m}^{2}, 0.49 \pm 0.22$ ), which is consistent with the simplified classification shown in Figure 5 . We believe that the increased proportions of smaller profiles represent regenerating nerve fibers, which is consistent with the shift to smaller sizes seen in histograms of regenerating peripheral nerves (Hoffman et al., 1984; Kaar and Fraher, 1985; Frykman et al., 1988; Bunker and Friede, 1989; Oblinger et al., 1989).

Relationship between mast cell and nerve densities. A cursory comparison of the different parts of Figures 4 and 5 indicates that the overall changes of nerve density and number in B-50or NSE-stained slides are not related to the mast cell distribution. However, a good positive correlation was determined between Alcian blue-stained mast cell and "small" B-50 nerve densities $\left(r=0.76, r^{2}=0.60, p=0.005\right)$, and an equally good negative correlation was obtained for IMMCs and "large" B-50 nerves $\left(r=-0.72, r^{2}=0.51, p=0.013\right)$. Both the "average" and total B-50-containing nerve densities exhibited comparatively poor relationships $\left(r=0.21, r^{2}=0.05, p=0.53\right.$ and $r=$ $0.19, r^{2}=0.03, p=0.59$, respectively).

\section{Discussion}

Our data suggest two phases of intestinal mucosal nerve remodeling in rats infected with Nippostrongylus brasiliensis: (1) initial degeneration of a proportion of the mucosal nerves, which occurs during the acute phase of inflammation; and (2) a subsequent reinnervation phase, which peaks at about $18 \mathrm{~d}$ and then gradually declines, but results in a higher density of innervation than in control animals. The evidence for this follows.

At $\mathrm{d} 10$ postinfection there was an increase in the mean nerve area in both B-50 (GAP-43)- and NSE-stained slides, compared with controls. Large nerve fibers accounted for more than half of the B-50-immunoreactive profiles seen at this time (Fig. 5b). A similar increase in mean nerve area was observed in the electron micrographs (Table 2). However, the mean number of axons measured in nerves at different time points was very similar. It was therefore not surprising that the calculated axonal areas were much larger at d 10 than in controls (Table 2), which is readily apparent in Figure 3. Regression and correlation analysis of the axon numbers and nerve areas revealed that nerve fiber size was dependent upon axon density in all animal groups $\left(r=0.58-0.65 ; r^{2}=0.34-0.42\right)$ but the regression coefficient, $b$, was three times larger at d 10 than in controls $(0.18$; cf. 0.06$)$, confirming the influence of an additional parameter, presumably axonal dilation.

Significant amounts of extraneuronal staining were seen in the d 10 NSE slides. This pattern was observed in repeated batches of slides but was not seen in any control animals or in animals at $\mathrm{d} 18$ postinfection and beyond. We interpret this to represent NSE that had diffused out of damaged nerves. Ultrastructural examination of animals $10 \mathrm{~d}$ after infection revealed many axons that were dilated and degenerate. Thus, the increased nerve areas measured in the B-50- and NSE-stained slides are related to degeneration and are not due to massive sprouting of axons during the acute phase of inflammation.

Sections from animals killed between $\mathrm{d} 18$ and $\mathrm{d} 28$ had predominantly smaller B-50- and NSE-immunoreactive processes within the lamina propria (Fig. 2). During this phase the absolute number of nerves per villus was similar to controls in the NSEstained slides and equivalent to or slightly greater than controls in the B-50 preparations (Fig. 4a); however, the mean nerve areas were below control values in all B-50 and some NSE preparations. Subclassification of the nerve profiles (Fig. $5 b$ ) revealed a large increase in the proportion of small nerve fibers during this phase of $\mathrm{Nb}$ infection, as well as a reduction in the frequency of the large, presumed damaged, nerves. Distribution analysis with the MIX program also revealed increased proportions of a small nerve population during this phase, but mix did not reveal an additional class of nerves. Although this type of morphometric assessment has not been used in the intestinal mucosa previously, and has mainly been applied to nerve-caliber changes during regeneration of peripheral myelinated fibers, distributions showing a shift to smaller fibers are considered to represent nerve regeneration (Hoffman et al., 1984; Kaar and Fraher, 1985; Frykman et al., 1988; Bunker and Friede, 1989; Oblinger et al., 1989).

In the last two groups of animals examined (d35 and d49), the pattern of innervation seen in the light microscope appeared similar to controls; however, the density or number per villus of B-50-immunoreactive fibers was $30 \%$ greater at d49 than in control animals killed at $\mathrm{d} 37(p<0.05)$, suggesting an overshoot phenomenon. These data alone indicate that nerve growth (regeneration/sprouting) had occurred in Nb-infected rats. Furthermore, at $\mathrm{d} 49$ the density of NSE-immunoreactive nerves had returned to control levels. Taking into account the earlier 
degenerative changes, either the damaged axons recovered or the extent of sprouting was greater than would appear from comparison of control and d49 animals only. Additional studies are required to determine if the increased B-50-immunoreactive nerve density persists, subsides, or increases further, and if the NSE stained population has actually recovered.

Quantitative analysis of the electron micrographs from animals 24 and $49 \mathrm{~d}$ after $\mathrm{Nb}$ infection resulted in mean nerve areas that were between those of $\mathrm{d} 10$ and control animals (although not statistically different from the noninfected group). However, the immunocytochemistry data suggest that the mean nerve areas at these times were less than or equal to controls. This discrepancy may be explained in terms of sampling differences. At the ultrastructural level, nerves were readily identifiable when they contained multiple axons or distinct organelles such as neurosecretory vesicles and/or microtubules, whereas small axonal sprouts admixed with numerous other cellular processes in the lamina propria could only occasionally be identified with confidence, especially in inflamed mucosae. Presumably, therefore, the electron micrographs represent larger nerve fibers, skewing the ultrastructural mean nerve areas to higher values.

It is not known if the nerves containing NSE and B-50 (or the axons present in these small fibers) are distinct or overlapping populations, nor what proportions of these are functional. The smaller numbers and areas of NSE-immunoreactive fibers might simply be due to low sensitivity of the technique used to localize this cytoplasmic enzyme, compared with intense labeling of the membrane-associated B-50. In fact, the clarity of NSE staining was poor, such that we had to use photographic transparencies (rather than a drawing tube) for measurement, which might also account for some of the differences between NSE and B-50 measurements. We think that the increased numbers of NSE-immunoreactive fibers seen in $\mathrm{d} 7$ and $\mathrm{d} 10$ postinfection animals can be similarly explained. Presumably, dilated nerve profiles were more readily detected, simply because of their greater size, although we cannot exclude the possibility of increased levels of NSE. NSE has previously been used as a measure of nerve growth by staining cell bodies in the spinal cord (Kirino et al., 1983), but it is not known if the levels of this enzyme change in degenerating or regenerating nerve fibers in vivo.

The differences between the data obtained for B-50 and NSE might be partially explained by the growth association of B-50 (GAP-43), if recently arrived axons contain little NSE but are strongly B-50 immunoreactive (Verhaagen et al., 1986; Tetzlaff et al., 1989). However, since the number of B-50-stained nerves was more than four times the NSE number in control animals, this would imply ongoing nerve modeling. The enhanced expression of B-50 could include the formation of growth cones (Van Lookeren Campagne et al., 1989) and axonal sprouts, as in regenerating peripheral nerves (Skene, 1989; Tetzlaff et al., 1989), as well as nerves in the early stages of degeneration, as reported elsewhere (Verhaagen et al., 1988; Tetzlaff et al., 1989). An earlier report by McGuire et al. (1988) included an illustration of B-50 immunoreactivity of the intestinal mucosa, without indicating the age of the animal studied or discussing the result. However, this has recently been fully documented by Sharkey et al. (1990), who also observed extensive B-50 immunoreactivity in normal rat intestines (as well as in human and ferret) and purified a substance with B-50-like electrophoretic characteristics from rat gut. These authors concluded that their find- ings were "consistent with a role for B-50 in the documented plasticity of the adult enteric nervous system."

It is interesting, then, that regenerating nerves are known to contain low levels of NFs (Hoffman, 1989; Tetzlaff and Bisby, 1989) and that only a few mucosal nerves were found to contain immunocytochemically detectable NFs in our study. This is consistent with earlier reports of only a proportion of mucosal nerves being demonstrated by silver stains (Schofield, 1968; Gabella, 1979) but in contrast to recent reports suggesting a more extensive distribution of NFs in the gut mucosa (Bjorklund et al., 1984; Bishop et al., 1985). Nevertheless, the relative densities of NFs and B-50 in our control rats suggest that the intestinal mucosal innervation may be in a state of ongoing modcling in normal animals.

The presumed degeneration and regeneration of the mucosal innervation can be temporally related to the recognized inflammatory changes during this nematode infection. We specifically looked at the mast cell population because of the known persistence of the associations of IMMCs and mucosal nerves in normal and diseased intestines (Stead et al., 1987b, 1989, 1990a). Hypothesizing that IMMCs might be innervated (Stead et al., $1990 \mathrm{~b}$ ), we predicted that a change in the density of this cell type would be accompanied by parallel changes of the local innervation (or vice versa), since this is known to apply to classical nerve/target relationships, such as voluntary muscle, as well as in the autonomic nervous system (Brown et al., 1981; Purves et al., 1988). Comparison of Figures 4 and 5 suggests that overall changes in nerve and mast cell densities are not related, which was confirmed by correlation analysis of the total B-50 population and IMMCs $(r=0.19)$; however, good correlations were determined for both "large" $(r=-0.72)$ and "small" ( $r=0.76)$ B-50-immunoreactive nerves and mast cells. Differences between the patterns of change of IMMC and nerves (Fig. 5) could be due to increased proportions of immature and/ or degranulated (and therefore unstained) IMMC during the acute inflammatory phase, especially at $\mathrm{d} 14$, the time of worm expulsion (Woodbury et al., 1984). Moreover, any trophic/tropic relationships between mast cells and nerves would likely be due to the release of regulatory factors, not only the relative densities of these two mucosal components. Thus, our data suggest nerve damage at the time of mast cell degranulation and reinnervation occurring in parallel with the increased IMMC numbers, although we have no evidence that these are connected.

That the Alcian blue stains were negative at d10, when granulated mast cells were not found in the electron microscope (data not shown), is an indicator of IMMC activation. At this time, extensive disruption of the extracellular matrix was also noted. Activation of IMMCs by antigen is known to cause the release of RMCP II, which acts directly on type IV collagen found in basement membranes (Woodbury et al., 1984; Patrick et al., 1988). Within the lamina propria, this includes subepithelial and perineural laminae. Mast cell-derived proteases may therefore be partially responsible for disruption of the mucosal nerve fibers and consequent degeneration. Macrophage or phagocytic activity was also prominent in the electron microscope in the $\mathrm{d} 10$ postinfection animals, which is consistent with the previously recorded peak in the number of monocytes/macrophages at this time (Befus et al., 1984). Phagocyte-like cells were often seen adjacent to nerves at $\mathrm{d} 10$ and may be involved in the remodeling of these fibers.

It is unclear if the observed regenerative changes are a direct, 
reactive consequence of the preceding degeneration or if locally produced factors are required. Whatever the stimulus for regeneration, if this was repetitive, ongoing remodeling (or simply modeling) might result. Since the "normal" intestinal mucosa contains significant numbers of chronic inflammatory cells, we speculate that mild, persistent inflammation perpetuates ongoing modeling of mucosal nerve fibers. Candidate mediators of this would include factors that act on both the immune and nervous systems. For example, the interleukins IL1, IL2, IL3, and IL6, which have a diverse array of effects on inflammatory cell populations, have all been shown to affect nerve growth (Lindholm et al., 1987; Satoh et al., 1988; Haugen and Letourneau, 1990; Kamegai et al., 1990), and 2.5S NGF induces proliferation in spleen mononuclear cell populations in vitro (Thorpe and Perez-Polo, 1987) and causes mast cell hyperplasia in vivo (Aloe and Levi-Montalcini, 1977; Stead et al., 1987a), in addition to its well-described actions on nerves (Levi-Montalcini, 1987). Since more rapid nerve regeneration can be induced by repeated insults (McQuarrie and Grafstein, 1973; McQuarrie, 1988), ongoing modeling of the mucosal innervation could also be partly conditioned.

It is well known that the inflammatory process involves the influx and proliferation of various immune cell types; however, little consideration has been given to the possibility of changes in nerve density in an inflammatory focus. If nerve degeneration does occur as part of a transient pathological process in the gut, the mucosa must subsequently be reinnervated, in order for normal function to be restored. There are several reports of axonal degeneration in both human and rodent intestines, and thickened submucosal nerves are observed in intestinal resections from patients with Crohn's disease (Bishop et al., 1980; Dvorak et al., 1980b; Sjolund et al., 1983; Yonei, 1987; Griffin et al., 1988; DeSchryver-Kecskemeti and Clouse, 1989; Di Giulio et al., 1989; Stead et al., 1989; Frantzides et al., 1990); however, we are not aware of any reports of nerve sprouting per se in an inflammatory situation in the gut. Our data suggest that nerve degeneration occurs predominantly during an acute inflammatory phase in $\mathrm{Nb}$-infected rats and that regeneration follows this. Additional studies are required to determine the mechanisms of nerve remodeling and if the mast cell is an important target or regulatory influence in this situation.

\section{References}

Aloe L, Levi-Montalcini R (1977) Mast cells increase in tissues of neonatal rats injected with the nerve growth factor. Brain Res 133: 358-366.

Arizono N, Matsuda S, Hattori T, Kojima Y, Maeda T, Galli SJ (1990) Anatomical variation in mast cell nerve associations in the rat small intestine, heart, lung, and skin: similarities of distances between neural processes and mast cells, eosinophils, or plasma cells in the jejunal lamina propria. Lab Invest 62:626-634.

Asbury AK, Johnson PC (1978) Pathology of peripheral nerve. Philadelphia: Saunders.

Befus AD, Bienenstock J (1979) Immunologically mediated intestinal mastocytosis in Nippostrongylus brasiliensis-infected rats. Immunology 38:95-101.

Befus AD, Johnston N, Bienenstock J (1979) Nippostrongylus brasiliensis: mast cells and histamine levels in tissues of infected and normal rats. Exp Parasitol 48:1-8.

Befus AD, Spencer JA, McDermott MR, McLaughlin B, Bienenstock J (1984) Isolation and characteristics of small intestinal lamina propria cells from normal and nematode (Nippostrongylus brasiliensis)-infected rats. Int Arch Allergy Appl Immunol 75:345-350.

Benowitz LI, Routtenberg A (1987) A membrane phosphoprotein associated with neural development, axonal regeneration, phospho- lipid metabolism, and synaptic plasticity. Trends Neurosci 10:527532.

Bishop AE, Polak JM, Bryant MG, Bloom SR, Hamilton S (1980) Abnormalities of vasoactive intestinal polypeptide-containing nerves in Crohn's disease. Gastroenterology 79:853-860.

Bishop AE, Carlei F, Lee V, Trojanowski J, Marangos PJ, Dahl D, Polak JM (1985) Combined immunostaining of neurofilaments, neuron specific enolase, GFAP and S-100. A possible means for assessing the morphological and functional status of the enteric nervous system. Histochemistry 82:93-97.

Bjorklund H, Dahl D, Seiger A (1984) Neurofilament and glial fibrillary acid protein-related immunoreactivity in rodent enteric nervous system. Neuroscience 12:277-287.

Brown MC, Holland RL, Hopkins WG (1981) Motor nerve sprouting. Annu Rev Neurosci 4:17-42.

Bunker E, Friede RL (1989) Changes in the histograms of nerves resulting from growth and various modalities of damage. Acta Neuropathol (Berl) 78:521-527.

Burns J, Graham AK, Frank C, Fleming KA, Evans MF, McGee JOD (1987) Detection of low copy human papilloma virus DNA and mRNA in routine paraffin sections of cervix by non-isotopic in situ hybridisation. J Clin Pathol 40:858-864.

Cleveland WS (1988) The collected works of John W. Turvey, Vol 5, Graphics (1965-1985). Cole Pacific Grove, CA: Wadsworth and Brooks.

DeSchryver-Kecskemeti K, Clouse RE (1989) Perineural and intraneural inflammatory infiltrates in the intestines of patients with systemic connective-tissue disease. Arch Pathol Lab Med 113:394-398.

Di Giulio AM, Tenconi B, La Croix R, Mantegazza P, Cattabeni F, Gorio A (1989) Denervation and hyperinnervation in the nervous system of diabetic animals. I. The autonomic neuronal dystrophy of the gut. J Neurosci Res 24:355-361.

Dimitriadou V, Buzzi MG, Moskowitz MA, Theoharides TC (1991) Trigeminal sensory fiber stimulation induces morphological changes reflecting secretion in rat dura mater mast cells. Neuroscience 44:97112.

Dollberg L, Gurevitz M, Freier S (1980) Gastrointestinal mast cells in health, and in coeliac disease and other conditions. Arch Dis Child 55:702-705.

Dunnett CW, Goldsmith CH (1989) When and how to decide to do multiple comparisons. In: Statistics in the pharmaceutical industry (Buncher CR, Tsay JY, eds), pp 397-433. New York: Dekker.

Dvorak AM, Monahan RA, Osage JE, Dickersin GR (1980a) Crohn's disease: transmission electron microscopic studies. II. Immunologic inflammatory response. Alterations of mast cells, basophils, eosinophils, and the microvasculature. Hum Pathol 11:606-619.

Dvorak AM, Osage JE, Monahan RA, Dickersin GR (1980b) Crohn's disease: transmission electron microscopic studies. III. Target tissues. Proliferation of and injury to smooth muscle and the autonomic nervous system. Hum Pathol 11:620-634.

Foreman JC, Jordan CC (1984) Neurogenic inflammation. Trends Pharmacol Sci 5:116-119.

Frantzides CT, Garancis JC, Doumas BT, Condon RE (1990) Chemical degeneration of intestinal nerves. Am J Physiol, Gastrointest Liver Physiol 258:G848-G855.

Frykman GK, McMillan PJ, Yegge S (1988) A review of experimental methods measuring peripheral nerve regeneration in animals. Orthop Clin North Am 19:209-219.

Gabella G (1979) Innervation of the gastrointestinal tract. Int Rev Cytol 59:129-193.

Galli SJ (1990) New insights into "the riddle of the mast cells": microenvironmental regulation of mast cell development and phenotypic heterogeneity. Lab Invest 62:5-33.

Galli SJ, Austen KF (1989) Mast cell and basophil differentiation and function in health and disease. New York: Raven.

Gorgels TGMF, Van Lookeren Campagne M, Oestreicher AB, Gribnau AAM, Gispen WH (1989) B-50/GAP43 is localized at the cytoplasmic side of the plasma membrane in developing and adult rat pyramidal tract. J Neurosci 9:3861-3869.

Griffin GE, Miller A, Batman P, Forster SM, Pinching AJ, Harris JRW, Mathan MM (1988) Damage to jejunal intrinsic autonomic nerves in HIV infection. AIDS 2:379-382.

Haugen PK, Letourneau PC (1990) Interleukin-2 enhances chick and rat sympathetic, but not sensory, neurite outgrowth. J Neurosci Res $25: 443-452$. 
Hoffman PN (1989) Expression of GAP-43, a rapidly transported growth-associated protein, and class II beta tubulin, a slowly transported cytoskeletal protein, are coordinated in regenerating neurons. J Neurosci 9:893-897.

Hoffman PN, Griffin JW, Price DL (1984) Control of axon calibre by neurofilament transport. J Cell Biol 99:705-714.

Kaar GF, Fraher JP (1985) The development of alpha and gamma motoneuron fibres in the rat. I. A comparative ultrastructural study of their central and peripheral axon growth. J Anat 141:77-88.

Kamegai M, Niijima K, Kunishita T, Nishizawa M, Ogawa M, Araki M, Ueki A, Konishi Y, Tabira T (1990) Interleukin 3 as a trophic factor for central cholinergic neurons in vitro and in vivo. Neuron 4: $429-436$.

Kiernan JA (1990) Degranulation of mast cells in the trachea and bronchi of the rat following stimulation of the vagus nerve. Int Arch Allergy Appl Immunol 91:398-402.

Kirino T, Brightman MW, Oertel WH, Schmechel DE, Marangos PJ (1983) Neuron-specific enolase as an index of neuronal regeneration and reinnervation. J Neurosci 3:915-923.

Koch TR, Carney JA, Go VLW (1987) Distribution and quantitation of gut neuropeptides in normal intestine and inflammatory bowel disease. Dig Dis Sci 32:369-376.

Koch TR, Carney JA, Go VLW (1988) Vasoactive intestinal peptide and the severity of colonic inflammation in ulcerative colitis. In: Inflammatory bowel disease: current status and future approach (MacDermott RP, ed), pp 25-30. Amsterdam: Elsevier.

Kowalski ML, Kaliner MA (1988) Neurogenic inflammation, vascular permeability, and mast cells. J Immunol 140:3905-3911.

Kowalski ML, Sliwinska-Kowalska M, Kaliner MA (1990) Neurogenic inflammation, vascular permeability, and mast cells. II. Additional evidence indicating that mast cells are not involved in neurogenic inflammation. II Immunol 145:1214-1221.

Levi-Montalcini R (1987) The nerve growth factor: thirty-five years later. EMBO J 6:1145-1154.

Lindholm D, Heumann R, Meyer M, Thoenen H (1987) Interleukin-1 regulates synthesis of nerve growth factor in non-neuronal cells of rat sciatic nerve. Nature 330:658-659.

Lloyd G, Green FHY, Fox H, Mani V, Turnberg LA (1975) Mast cells and immunoglobulin $\mathrm{E}$ in inflammatory bowel disease. Gut 16:861866.

Macdonald PDM, Pitcher TJ (1979) Age-groups from size-frequency data: a versatile and efficient method of analysing distribution mixtures. Fish Res Bd Can 36:987-1001.

MacQueen G, Marshall J, Perdue M, Siegel S, Bienenstock J (1989) Pavlovian conditioning of rat mucosal mast cells to secret rat mast cell protease II. Science 243:83-85.

McGuire CB, Snipes GJ, Norden JJ (1988) Light-microscopic immunolocalization of the growth- and plasticity-associated protein GAP43 in the developing rat brain. Brain Res 469:277-291.

McQuarrie IG (1988) Neuronal metabolic basis of the conditioning lesion effect. In: Post-lesion neural plasticity (Flohr H, ed), pp 113122. Berlin: Springer.

McQuarrie IG, Grafstein B (1973) Axon outgrowth enhanced by a previous nerve injury. Arch Neurol 29:53-55.

Miller RG (1981) Simultaneous statistical inference. New York: Springer-Verlag.

Nennesmo I, Reinholt F (1986) Mast cells in nerve end neuromas of mice. Neurosci Lett 69:296-301.

Newson B, Dahlstrom A, Enerback L, Ahlman H (1983) Suggestive evidence for a direct innervation of mucosal mast cells. An electron microscopic study. Neuroscience 10:565-570.

Oblinger MM, Szumlas RA, Wong J, Liuzzi FJ (1989) Changes in cytoskeletal gene expression affect the composition of regenerating axonal sprouts elaborated by dorsal root ganglion neurons in vivo. J Neurosci 9:2645-2653

Oestreicher AB, Gispen WH (1986) Comparison of the immunocytochemical distribution of the phosphoprotein B-50 in the cerebellum and hippocampus of immature and adult rat brain. Brain Res 375: 267-279.

Olsson Y (1968) Mast cells in the nervous system. Int Rev Cytol 29: 27-70.

Patrick MK, Dunn IJ, Buret A, Miller HRP, Huntley JF, Gibson S, Gall DG (1988) Mast cell protease release and mucosal ultrastructure during intestinal anaphylaxis in the rat. Gastroenterology 94:1-9.
Pepys J, Edwards AM (1979) The mast cell: its role in health and disease. Tunbridge Wells: Pitman.

Purves D, Snider WD, Voyvodic JT (1988) Trophic regulation of nerve cell morphology and innervation in the autonomic nervous system. Nature 336:123-128.

Ranlov P, Nielsen MH, Wanstrup J (1972) Ultrastructure of the ileum in Crohn's disease. Immune lesions and mastocytosis. Scand J Gastroenterol 7:471-476.

Rao SN (1973) Mast cells as a component of the granuloma in Crohn's disease. J Pathol 109:79-82.

Satoh T, Nakamura S, Taga T, Matsuda T, Hirano T, Kishimoto T, Kaziro Y (1988) Induction of neuronal differentiation in PC12 cells by B-cell stimulatory factor 2/interleukin 6 . Mol Cell Biol 8:35463549.

Schofield GC (1968) Anatomy of muscular and neural tissues in the alimentary canal. In: Handbook of physiology, Sec 6, Alimentary canal, Vol 4, Motility (Code CF, ed), pp 1573-1627. Washington: American Physiological Society.

Seelig LL Jr, Schlusselberg DS, Smith WK, Woodward DJ (1985) Mucosal nerves and smooth muscle relationships with gastric glands of the opossum: an ultrastructural and three-dimensional reconstruction study. Am J Anat 174:15-26.

Sharkey KA, Coggins PJ, Tetzlaff W, Zwiers H, Bisby MA, Davison JS (1990) Distribution of growth-associated protein, B-50 (GAP-43) in the mammalian enteric nervous system. Neuroscience 38:13-20.

Shaw G, Osborn M, Weber K (1986) Reactivity of a panel of neurofilament antibodies on phosphorylated and dephosphorylated neurofilaments. Eur J Cell Biol 42:1-9.

Sjolund K, Schaffalitzky de Muckadell OB, Fahrenkrug J, Hakanson R, Peterson BG, Sundler F (1983) Peptide-containing nerve fibres in the gut wall in Crohn's disease. Gut 24:724-733.

Skene JHP (1989) Axonal growth-associated proteins. Annu Rev Neuorsci 12:127-156.

Stead RH, Bienenstock J, Stanisz AM (1987a) Neuropeptide regulation of mucosal immunity. Immunol Rev 100:333-359.

Stead RH, Tomioka M, Quinonez G, Simon GT, Felten SY, Bienenstock J (1987b) Intestinal mucosal mast cells in normal and nematodeinfected rat intestines are in intimate contact with peptidergic nerves. Proc Natl Acad Sci USA 84:2975-2979.

Stead RH, Dixon MF, Bramwell NH, Riddell RH, Bienenstock J (1989) Mast cells are closely apposed to nerves in the human gastrointestinal mucosa. Gastroenterology 97:575-585.

Stead RH, Franks AJ, Goldsmith CH, Bienenstock J, Dixon MF (1990a) Mast cells, nerves and fibrosis in the appendix: a morphological assessment. J Pathol 161:209-219.

Stead RH, Perdue MH, Blennerhassett MG, Kakuta Y, Sestini P, Bienenstock J (1990b) The innervation of mast cells. In: The neuroendocrine-immune network (Freier S, ed), pp 19-37. Boca Raton: CRC.

Stead RH, Kosecka-Janiszewska U, Dixon MF, Oestreicher AB, Bienenstock J (1990c) Remodelling of rat intestinal mucosal nerves after nematode infection. Gut 31:A621.

Stevens RL, Austen KF (1989) Recent advances in the cellular and molecular biology of mast cells. Immunol Today 10:381-386.

Symons LEA, Fairbairn D (1962) Pathology, absorption, transport, and activity of digestive enzymes in rat jejunum parasitized by the nematode Nippostrongylus brasiliensis. Fed Proc 21:913-918.

Taliaferro WH, Sarles MP (1939) The cellular reactions in the skin, lungs and intestine of normal and immune rats after infection with Nippostrongylus muris. J Infect Dis 64:155-192.

Tetzlaff W, Bisby MA (1989) Neurofilament elongation into regenerating facial nerve axons. Neuroscience 29:659-666.

Tetzlaff W, Zwiers H, Lederis K, Cassar L, Bisby MA (1989) Axonal transport and localization of B-50/GAP-43-like immunoreactivity in regenerating sciatic and facial nerves of the rat. J Neurosci 9:13031313.

Thorpe LW, Perez-Polo JR (1987) The influence of nervegrowth factor on the in vitro proliferative response of rat spleen lymphocytes. J Neurosci Res 18:134-139.

Van Lookeren Campagne M. Oestreicher AB, Van Bergen en Henegouwen PMP, Gispen WH (1989) Ultrastructural immunocytochemical localization of B-50/GAP43, a protein kinase C substrate, in isolated presynaptic nerve terminals and neuronal growth cones. J Neurocytol 18:479-489.

Verhaagen J, Van Hooff COM, Edwards PM, De Graan PNE, Oestreicher AB, Schotman P, Jennekens FGI, Gispen WH (1986) The 
kinase C substrate protein B-50 and axonal regeneration. Brain Res Bull 17:737-741.

Verhaagen J, Oestreicher AB, Edwards PM, Veldman H, Jennekens FGI, Gispen WH (1988) Light- and electron-microscopical study of phosphoprotein B-50 following denervation and reinnervation of the rat soleus muscle. J Neuorsci 8:1759-1766.

Weibel ER (1979) Stereological methods, Vol l, Practical methods for biological morphometry, p 321. London: Academic.

Woodbury RG, Miller HRP, Huntley JF, Newlands GFJ, Palliser AC, Wakelin D (1984) Mucosal mast cells are functionally active during spontaneous expulsion of intestinal nematode infections in rat. Nature $312: 450-452$.

Yonei Y (1987) Autonomic nervous alterations and mast cell degranulation in the exacerbation of ulcerative colitis. Jpn J Gastroenterol 84:1045-1056

Yonei Y, Oda M, Nakamura M, Watanabe NH, Tsuskada N, Komatsu HK, Akaiwa Y, Ichikawa E, Kaneko K, Asakura H, Fujiwara T, Tsuchiya M (1985) Evidence for direct interaction between the cholinergic nerve and mast cells in rat colonic mucosa. J Clin Electron Microsc 18:560-561. 